\title{
Controlling Hoax of Covid-19: Capturing Moral Messages from Social Events
}

\author{
Oksiana Jatiningsih $^{1, *}$, Windita Mei Bella Averina ${ }^{2}$, Miftakhul Hidayah ${ }^{3}$
}

\author{
1,2,3 Universitas Negeri Surabaya, Surabaya, Indonesia \\ *Corresponding author.Email: oksianajatiningsih@unesa.ac.id
}

\begin{abstract}
The corona 19 virus pandemic requires everyone to understand and realize how each individual has an important role in controlling the spread. Learning from home policies, working from home, social distancing, or not going home before Eid, which are proclaimed by the government will only be perceived as a problem and fail if it does not involve individual awareness and participation to implement it. Therefore, each individual plays an important role in the process. In the Covid-19 pandemic, there have been many positive and negative events in character education. Social media may present a lot of news that contains moral values or vice versa as an arena for character education. According to social learning theory, the social environment can become a laboratory and arena for character education. This paper is based on a qualitative analysis using news presented on social media. It is important for each individual to present himself as a person who can place himself in synergy as an important part of life together. Reading critically a variety of news containing moral aspects is important in the context of character education for children during the learning from home period. We must be trained critically in understanding a message (textual and contextual/hidden messages). For the purpose, always keep skeptic in reading news and understanding the social context. Both are very important in capturing the hidden meaning of a message. By habituation of this learning activity, we do not easily trap in hoax or fake news. Finally, capturing moral messages will appropriately reflect the quality of their personal and social skills.
\end{abstract}

Keywords: Covid-19, Critical Thinking, Hoax, Moral Message.

\section{INTRODUCTION}

The spread of the corona virus (covid-19) has reached an alarming limit. Therefore, a number of policies have been issued by the government, such as Government Regulation number 21 of 2020 concerning Large-Scale Social Restrictions (PSBB) to protect citizens from exposure to the virus. LargeScale Social Restrictions are restrictions on certain activities of residents in an area suspected of being infected with Corona Virus Disease 2019 (COVID-19) in such a way as to prevent possible spread. For that, at least it is necessary to: (a) holidays from schools and workplaces; (b) restrictions on religious activities; and/or (c) limitation of activities in public places or facilities. Consequently, everyone is encouraged to limit socializing activities with many people, reduce activities outside the home, stay away from crowds, and limit going out. Consequently, offices and schools were closed to reduce contact massively from people [1]

In the beginning, learning and working activities for a moment become "stopped" without direction. Many do not understand that learning from home is not a school holiday. In accordance with Circular Letter Number 4 of 2020 concerning the Implementation of Education in the Emergency Period for the Spread of Covid-19, "Learning from Home can be focused on life skills education, including regarding the Covid-19 pandemic." Life skills to deal with COVID-19 are an important content in a meaningful learning process. In the process, important learning is carried out based on the four pillars of education to form and build a mindset through education, namely learning: (1) how to know; (2) how to do; (3) how to be; and (4) how to live together.

Various problems arise related to the implementation of LFH. Initially, LFH was interpreted as a holiday. After the passage of time, how children can learn well is also a problem. The research of Jatiningsih et. al. describe how parents, especially mothers, have to "take over" some of the teacher's roles and involve themselves in their child's learning process from home [1]The roles of parents in this learning 
process are: (1) maintaining children's motivation; (2) facilitating children's learning; (3) foster children's creativity; and (4) supervising children in learning [3]. A heavy burden is felt on children and parents, especially for parents who are cognitively and economically incapable. The limited facilities and infrastructure for children's online learning become an obstacle to children's learning. Furthermore, the increasing opportunity for children to use the internet and social media is also a problem.

The situation becomes even more complicated when a lot of hoax news circulates along with the strength of the Covid-19 problem. This is another problem in education and life. Hoax is information that contradicts the facts, including misinformation [4], so that it can cause confusion in the community in determining the truth of the information. Hoax is information that is engineered, either by distorting the facts or obscuring the information, so that the true message cannot be received by someone [5]. It was further explained, referring to the First Draft category, the Indonesian Anti-Defamation Society (Mafindo) categorizes seven types of hoaxes, namely: satire or parody, misleading content, Imposter content, Fabricated Content, False connection, False context, and Manipulated content.

The surrounding environment is very conducive to the acquisition of experiences that lead to the growth and achievement of knowledge [6][7]. Therefore, education plays an important role in growing children's ability to counter and act counterproductively against hoax messages and fake new. The emergence of social media is not only a means to facilitate human relations, but also makes it easier for hoax information to spread [8][9]. This is very important in the learning process, because the distance between children and social media is so close.

Hoax or "fake" news gets its power because it is widely discussed. They may to motivated reasoning, political agendas, or simple, but because repetition instigated local networks of coherent references that made this information more believable [10]. The results of a study by Jonah Berger and Katherine Milkman, news that is shared virally through social media is able to evoke very strong positive and negative emotions [11]. Therefore, this paper reveals how do we build individual's skills in order to capture the moral message of news?

\section{THEORETICAL REVIEW}

The emergence of social media and the habit of sharing messages suddenly, without first reading the message, strengthens the spread of hoax news. Wrapping jokes in a hoax news also exacerbates the process of sharing information without realizing the impact. Study of Jonah Berger and Katherine Milkman [11] revealed that the news that was shared virally through social media was news that was able to evoke very strong positive and negative emotions.
Hoax is information that is engineered, either by distorting the facts or obscuring the information, so that the true message cannot be received by someone. [5] Fake news in the ITE Law aims to deceive, create feelings of hatred or hostility to certain individuals and/or community groups based on SARA (Law Number 19 of 2016 concerning Amendment to Law Number 28 of 2008 concerning Information and Electronic Transactions). In a situation full of lies, the progress and amount of internet use in Indonesia has made social media platforms such as Facebook, Twitter, WhatsApp, Instagram are effective devices of distributing hoaxes. Incitement to fake or hoax news causes many problems. Not only does it make someone miss the opportunity to get to the truth, but the impact of the news can result in the following. (1) degrading human dignity, especially for marginalized groups; (2) fostering prejudice and discrimination; (3) trigger violence/hate crimes; (4) triggering violent crime/hate and other violence; (5) can trigger intergroup conflict, even ethnic-cleansing.

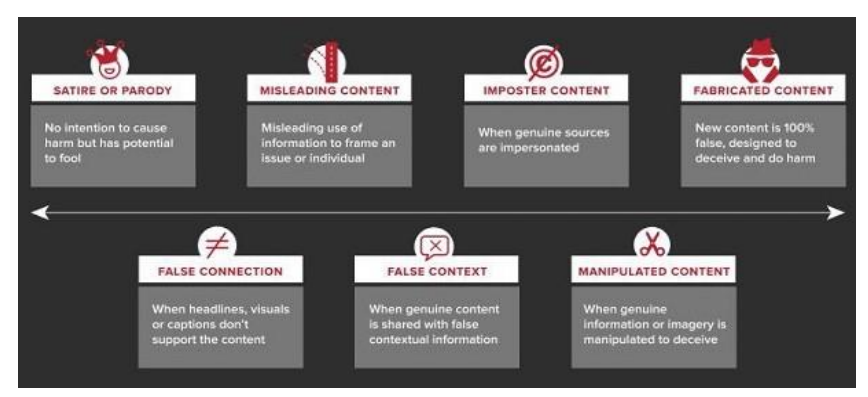

Figure 1 Types of misinformation and disinformation in society

Hoax includes information clutter that includes misinformation, disinformation, and malinformation Misinformation is information that is not true but the person who spreads it believes that the information is true. There are seven types of misinformation and disinformation that are spread in the media. Disinformation is information that is untrue and intentionally spread to deceive, threaten, or even harm others. In addition, there is also the term malinformation, which is a kind of incitement to hatred, namely information that is true but is used to threaten the existence of a person or group of people with a certain identity.

Satire or parody is a satire directed to a person or event which is usually wrapped in a humorous context. But the problem is, the context of the humor is not always understood by the readers, so it may lead to misinformation. This is something that everyone really needs to understand so as not to get caught up in hoax messages packaged in this satire. Children have seen a lot of shows that many adult humans are less concerned about the safety of themselves and others by not limiting their social activities in crowds, cangkruk, walking, or other actions that are actually contrary to government policy in the context of controlling and preventing transmission. Covid-19. How to understand and convince children that each individual plays an 
important role and is responsible for breaking the spread of Covid-19 is one form of character education that must be carried out during the LFH process. Children are also very close to hoax news which can undermine their obedience to carry out their obligations and responsibilities to maintain personal and social safety during this pandemic.

Based on the analysis, there are two important things to do, namely building individual's critical think skills which can be done by capturing hidden messages and understanding the social context of a message. The procedures that can be done are: find the textual messages of news, understand the social context, think and find the message in the frame of the contextual situation of a message, find the moral messages of news, and decide the position toward news.

\subsection{Be Skeptic in Reading News}

The government's appeal to keep a distance from other people in the form of Work from Home (WFH), Studying from Home (LFH) policies, social distancing, and physical distancing were not taken seriously by some people. Even the policy is also considered by many people as a policy that ignores the interests of the people. The behavior of the streets still occurs, as well as the behavior of hanging out and hanging out in coffee shops. Many people do not care about the call for social distancing or physical distancing, so the police must move to disperse them. This is certainly a learning experience that is also observed and recorded by the child. Many people feel the appeal is farfetched. Various responses that sound like jokes are also circulating on social media to respond to the situation and government policies during this pandemic.

Hoax news about the Covid-19 vaccine has circulated in Indonesia from November 2020 to January 2021. There are around 10,600,000 news stories with the keywords hoax and Covid-19 [12]. The Ministry of Communication and Information (Kominfo) found six hoaxes about the Covid-19 corona virus circulating on social media (coverage 6.com. 21 February 2021), among others stating that Covid-19 emerged because of rapid tests and PCR. Data from the Ministry of Communication and Information states that there are around 800,000 sites in Indonesia that have been indicated as spreading false information [13]. With the situation of many hoax news and situations that cause people to socialize more and more through social media, including children, the ability to understand the news properly, to control themselves, and to be wise is very important. Some hoax news that have made many people refuse to be vaccinated, for example about the Covid-19 vaccine which contains dangerous ingredients such as borax, formalin, vero cells, even made from baby boy fetuses; vaccine side effects such as death, infertility, enlarge male genitalia, and modify human DNA; unwillingness of the Indonesian Doctors Association to be vaccinated for the first time [12].

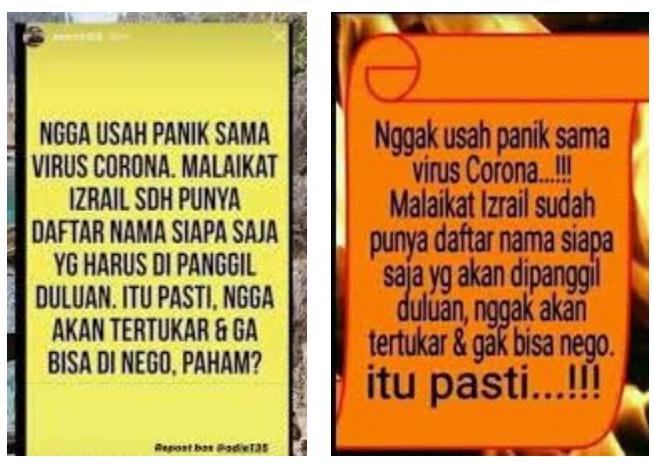

Figure 2 Satire Covid-19 of Angel Izrail

Hoax comes in various ways; one of them uses jokes as a way to convey ideas and influence the way people think. Satire is writing that uses humor, irony, and exaggeration to comment on current events. What message can be captured from this article? In the situation of implementing PSBB, the message actually provokes people not to worry because death has a definite determination. This spirit rejects the call to maintain social distance.

The message circulated on social media at the beginning of the PSBB policy. The implied message to be conveyed is that death must be present based on destiny when the time comes. But behind that there is also a hidden message that obeying the rules for not crowding and maintaining distance is not really necessary because in fact death will not come if it is not yet time. Based on the contents of the message, it can be read that there is an invitation not to care about the policy of self-limiting and keeping a distance, because if it is not time for someone to die, it is unlikely that someone will die from the dangerous corona. This article is provocative to disobey the rules. Wrapped in a joke, the article said that the corona virus 19 would not be the cause of someone's death if someone had not been destined to die. Based on that message, one does not need to be afraid to leave the house, hang out with friends, or just hang out, because the fate of death is more decisive than the threat of the corona virus.

\subsection{Critical Capture the Social Context of a Message}

Without critical thinking, this can provoke people to follow the content of the message. Forward the message, because it is considered funny. Without critical thinking, someone will easily share a message, without exploring the meaning contained in the message. The low interest in reading makes it easy to do this behavior without paying attention to the content of the message [14]. 


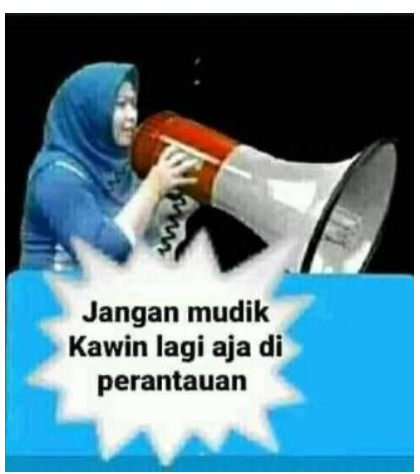

Figure 3 Rejecting the Prohibition of Going Home

The message is relatively the same because Covid19 is also presented through the mention of a list of names of someone's death that has been recorded on the angel of death Azrael. The death of a person is indeed not something that can be avoided and rejected, but feeling sure that he will not die because he has not registered a death is not something that should be done. Challenging death is behavior that is not in accordance with the human obligation to maintain his safety. The provocation to not needing health protocols can be found in the joke.

Another message that implies a disapproval of the government's policy to delay returning to the village also occurs in the following message. This message assumes that the husband and wife who migrate are in the house located in the village. "Marriage again" is a solution if the government is forbidden to return home. It's not easy not to carry out the tradition of returning home on holidays, but by thinking clearly it becomes easier. This is a message that, if studied further, is provocative to disobey the rules. This message oversimplifies a phenomenon.

Good society is an important part in the process of handling Covid-19. From this view, children learn about the images of being good citizenship. As stated by Ruth Benedict [15] in a good society it is always marked by a cultural feature of "synergy". Synergy is a value commitment that transforms "me and you", individuals and society, and our roles. Therefore, synergy is not a compromise. Therefore, synergy requires a commitment to the involvement of each individual. A good society will only exist if the individual becomes part of a good citizen. This is where individual strengths are important to be created in order to be part of a good society.

According to Nukman Luthfie, there are three short-term steps to fight hoaxes, namely: law enforcement, involving platform organizers, and public education. An important role that individuals can take is to provide continuous education, both to themselves and to others. It should always be remembered that everyone plays an important role in the process.

There is an important thing to remember that the more you talk about a message, the more likely it is to be found in the social space. Repeated lies can displace hard truths [16]. Seeing the current power of Google, Facebook, or Twitter, the step that needs to be taken to reduce the destructive power of social media is to grow digital media literacy. For this reason, individual digital literacy skills are very important. Giving other people the opportunity to read a message is to provide fertile space for them to grow into new truths. Therefore, bracketing and turning off the message is a way to stop hoaxes.

\section{CONCLUSION}

Based on the discussions, it can be stated that the COVID-19 pandemic is a character learning room for everyone. Learning from valuable lessons about Covid19 , both good and negative examples of events become copies of critical events that can be used as learning resources in character education.

Character education is part of efforts to form good citizens. As part of a good society, it is important for each individual to present themselves as individuals who can place themselves in synergy as an important part of living together. Capturing messages and acting appropriately is not a simple process. We must be trained critically in understanding a message (textual and contextual/hidden messages). For the purpose, always keep skeptic in reading news. Understanding the social context is very important in capturing the hidden meaning of a message. By habituation of this learning activity, we do not easily trap in hoax or fake news. Finally, capturing moral messages will appropriately reflect the quality of their personal and social skills the quality of their personal and social skills.

\section{REFERENCES}

[1] R. H. Syah, "Dampak Covid-19 pada Pendidikan di Indonesia: Sekolah, Keterampilan, dan Proses Pembelajaran," SALAM J. Sos. dan Budaya Syari, vol. 7, no. 5, 2020, doi: $10.15408 /$ sjsbs.v7i5.15314.

[2] O. Jatiningsih, S. M. Habibah, R. Wijaya, and M. M. K. Sari, "Peran Orang Tua dalam Pemenuhan Hak Pendidikan Anak pada Masa Belajar dari Rumah," J. Ilmu Sos. dan Hum., vol. 10, no. 1147-157, 2021.

[3] I. K. Suparya, "Belajar dari Rumah Selama Masa Pendemi Covid 19," COVID-19 Perspekt. Pendidik., 2020.

[4] I. Nadzir, S. Sari Seftiani, and Y. Permana, "Hoax and Misinformation in Indonesia: Insights from a Nationwide Survey," ISEAS -Yusof Ishak Inst. Anal. Curr. Events, vol. 92, 2019.

[5] A. dkk. Nursaid, Buku Panduan Melawan Hasuan Kebencian. Jakarta: Pusat Studi Agama dan Demokrasi (PUSAD), Yayasan Paramadina Masyarakat Anti Fitnah Indonesia (Mafindo), 2019.

[6] J. Dewey, "Experience and education," Educ. Forum, vol. 50, no. 3, 1986,

[7] J. Dewey, "Experience and Education (Kappa Delta Pi Lecture)," in

[8] V. Yuliswara, "Mengembangkan Model Literasi Media yang Berkebhinnekaan dalam 
Menganalisis Informasi Berita Palsu (Hoax) di Media Sosial," J. Pemikir. Sosiol., vol. 4 Nomor 2, no. Agustus 2017, pp. 143-`64, 2017.

[9] A. Aminah and N. Sari, "Dampak Hoax di Media Sosial Facebook terhadap Pemilih Pemula," J. Komun. Glob., vol. 8, no. 1, pp. 51-61, 2019, doi: 10.24815/jkg.v8i1.13565.

[10]C. Unkelbach and A. Koch, "Gullible but functional?: Information repetition and the formation of beliefs," in The Social Psychology of Gullibility: Conspiracy Theories, Fake News and Irrational Beliefs, 2019.

[11] J. Berger and K.; L. Milkman, "What makes online content viral?," J. Mark. Res., vol. 49, no. 2, 2012, doi: 10.1509/jmr.10.0353.

[12] R. N. Rahayu and Sensusiyati, "Analisis Berita Hoax Covid - 19 Di Media Sosial Di Indonesia," J. Ekon. Sos. Hum., vol. 1, no. 9, 2020.

[13]F. Taufiq, "Cerdaslah dalam Memanfaatkan Media Sosial"." 2021.

[14] W. Widodo, S. Budoyo, T. G. W. Pratama, and T. Soeprijanto, "Hoax Di Indonesia : Suatu Kajian," J. Meta-Yuridis, vol. 2, no. 1, pp. 69-78, 2019.

[15]P. Wirutomo, Perjalanan Sosiologis Revolusi Mental. Jakarta: Kementerian Koordinator Pembangunan Manusia dan Kebudayaan, 2019.

[16]D. G. Myers, "Psychological Science Meets a Gullible Post-Truth World," in The Social Psychology of Gullibility, 2019. 